\title{
High School Teachers' Course Designs and Their Professional Knowledge of Online Teaching
}

\author{
Teemu VALTONEN, Jari KUKKONEN \\ University of Joensuu \\ P.O. Box 111, 80101 Joensuu, Finland \\ e-mail: teemu.valtonen@joensuu.fi, jari.kukkonen@joensuu.fi
}

\author{
Anu WULFF \\ ISOverkosto \\ Vuorikatu 27 C, 70100 Kuopio, Finland \\ e-mail: anu.wulf@kuopio.fi
}

Received: May 2006

\begin{abstract}
This paper deals with the process of expanding the virtual secondary education school network, aiming to provide daily basis, online teaching. The context of this research is the ESR funded Eastern Finland Educational Network Project, which is a network of 36 high schools providing courses via web-based learning environments. The project is a shared activity between teachers and researchers. The aim of the present study is to investigate teachers' technological pedagogical content knowledge by finding out what kind of pedagogical solutions the teachers use while designing and carrying out online teaching. In this study thirteen online courses were analysed and based on the analysis, four different course design patterns were found. The most general approach in course designs seems to be teacher centred, focusing on well guided individual learning processes. There seems to be need for development of teacher technological pedagogical content knowledge, to support approaches of more collaborative course designs.
\end{abstract}

Key words: online teaching, technological pedagogical content knowledge, meaningful learning.

\section{The Expanding Virtual High School Network as an Arena for Professional Development and Shared Activity}

This paper deals with aspects of the process of expanding the virtual secondary education school network, aiming to provide daily basis online teaching, with in-service training and research related to it. The context of this research is the ESR funded Eastern Finland Educational Network Project (later referred as ISOverkosto), which is a network of 36 high schools providing courses via web-based learning environments (Virnes and Suonio, 2004). The ISOverkosto project has a core group comprising of eight, mainly adult high schools which act as experts, due to their previous four to five year experience on distance, and online teaching. Their online teaching skills, web-based courses, and experience of teaching online, are shared in this project by those high schools which do not have so much experience in web-based education. There is a continual process to 
design teaching to meet the needs of the renewed curriculum of high schools in Finland, and therefore many of the previously conducted courses have to be revised. This revision offers the opportunity not only to change the online environment but also to revise the course content as was requested. To some extent it is also due to the revision of the matriculation examination. Many small high schools are forced to include advanced level courses for small groups of students, and therefore shared resources are needed in order to fulfil this demand.

In this kind of network of educational institutions, there are persons involved at many different levels, using their innovation both from the preparation stage, to the renewal (Jennings and Dirksen, 1996). This project has been a revision process of the online courses for experienced teachers, and the start of the web-based learning environment for beginners. It has also been a shared activity between teachers and researchers in which support was arranged by asking teachers to externalise their pedagogical ideas to local tutors, e.g., with some key aspects of pedagogical content knowledge (Shulman, 1986). In this case these courses also served as pilot environments for many high schools which are adopting web-based teaching as a part of their educational activities. In these socalled 'training' online courses, beginner online teachers operated as co-teachers or local tutors and were thus made familiar with teaching and learning online. Therefore we believe that the in-service education resembles the cognitive apprenticeship method and it utilises technology to support the working process for communities of learners. Cognitive apprenticeship attempts include domain knowledge, heuristic knowledge, metacognitive strategies and learning strategies. This is done in an authentic real-life context in which by scaffolding, an individual or an organisation can support the construction of its own understanding of the problem in hand. Cognitive apprenticeship includes teaching and learning strategies such as: articulating one's own reasoning process, monitoring the knowledge construction or the problem solving process, reflection on the process in order to find better or more general ways of thinking, and the modelling of the effective process (Collins et al., 1989). The aim of the present study is to concentrate on teachers' technological pedagogical content knowledge, to find out what kind of pedagogical solutions the teachers use while designing and carrying out online teaching. We feel that it is important to understand teachers' pedagogical thinking in the real life context of online teaching, and the use of ICT in education. The research also provides information on further activities relating to the project, especially in-service training, aiming to support teachers' professional development in the area of ICT in education.

\section{Theoretical Perspectives on the Design of Meaningful Online Learning}

Nowadays research concerning the use of information and communication technology in teaching and learning, e.g., in web-based learning environments, emphasizes the idea of computer supported collaborative learning (Harasim, 2000; Koschmann, 1996). Computer supported collaborative learning (CSCL) stresses peer interaction, sharing and the distributing of knowledge and expertise among members of the course (Lipponen, 2002). 
CSCL is based on the idea that with computer applications we can scaffold and implement advanced socio-cognitive processes for knowledge sharing and knowledge building (Paavola et al., 2002). According to these ideas the most important role of the web-based learning environment is to support teachers' and learners' interaction to construct knowledge and reflect on their own learning. There are several research based pedagogical models to support collaborative learning (Joyce and Weil, 1986; Schank and Cleary, 1995). These models provide guidelines on how to design online courses that support learners' collaborative knowledge construction. Still the use of collaborative, learner centred methods is not a trivial task, especially for teachers who have little experience in online teaching and learning.

Teacher thinking, and ways of using different teaching methods and equipment, have been studied both at the conceptual level and also at the more concrete level in the context of ordinary classroom teaching. There have been several studies on teachers' conceptions of teaching and learning, they show that teachers' conceptions of learning vary between the transferring of knowledge to conceptions which emphasize more studentcentred, constructive teaching and learning methods (Marton et al., 1993; Kember, 1997; Boulton-Lewis et al., 2001). Teacher thinking and activity have also been studied at a more concrete level using concepts like teachers' classroom practices (Mellado, 1998), personal practical theories (Cornet et al., 1990) interactive thinking (Clark and Peterson, 1986), teachers' practical theories (Marland, 1998; Marland and Osborne, 1990) and teachers' pedagogical content knowledge (Shulman, 1986, 1987). Pedagogical content knowledge (PCK) is a blending of knowledge about the content to be studied and knowledge about pedagogy. Content knowledge contains knowledge which includes important theories and concepts and also the nature of the knowledge and inquiry of the field. Pedagogical knowledge comprises of different teaching practices and methods to support meaningful understanding, and comprehension as to how learners construct knowledge. PCK, the mixture of these elements, means the teachers' knowledge on how to represent and formulate content knowledge which is easy for learners to attain and understand. PCK contains techniques and strategies to foster meaningful learning, it also contains knowledge on the aims of the courses, difficult areas of the topic, information about the learners, the curriculum and the learning context (Shulman, 1986, 1987; Mishra and Koehler, in press).

Although there have always been different types of technologies available in schools, the growing role of educational technology, digital technology, causes changes in the traditional model of teachers' pedagogical content knowledge. Mishra and Koehler (in press) have studied the design process of online teaching and added technology related concepts to teachers' pedagogical content knowledge. They have started to use technological pedagogical content knowledge (TPCK) in describing teachers' knowledge in terms of teaching with technology (Mishra and Koehler, in press). TPCK includes the teachers' own knowledge about different types of technology such as skills needed to operate computers, and different software. Furthermore it contains knowledge on how technology may expand or constrain the possibilities to represent content knowledge to support students learning (technological-content knowledge). TPCK also includes knowledge the 
what kinds of possibilities learning technology provides, to make it possible for teaching and learning to realize their pedagogical aims (technological-pedagogical knowledge). Teachers' TPCK should include the vision of combining pedagogy and content to support constructivist learning and so take into account different learners who have different prior knowledge and learning methods in the use of educational technology (Mishra and Koehler in press).

TPCK conceptualises the demands for teachers' knowledge and skills, in order to be able to implement course designs that fulfil Jonassens' (1995) criteria of meaningful learning. According to Jonassen (1995) meaningful learning can be characterised as constructive, reflective, collaborative, conversational, active, intentional and contextual. In this article we prefer to combine qualities of meaningful learning: reflective and constructive to constructive, and collaborative and conversational to co-operative, as presented by Jonassen et al. (1999). Shortly described as follows:

Active: The role of the learners should be active and they should be responsible for the results. The learning environment should offer possibilities to manipulate and apply objects and knowledge to construct new knowledge and comprehension. (Jonassen, 1995; Jonassen et al., 1999)

Constructive and reflective: According to this quality, learners should be able to actively construct new knowledge based on their prior knowledge. An important part in this process is reflection. The learning environment should support students' own evaluation of their learning and prior knowledge, in order to meet the needs of the new situation (Jonassen et al., 1999).

Intentional: Intentionality emphasizes the importance of the learners' own aims and goals. Learners should define their own learning goals and they should be able to reflect the progress of process (Jonassen et al., 1999).

Cooperative: The aim is to create learning communities to enhance the social negotiation of shared understanding. The learning environment should encourage learners to share, reflect on and construct new knowledge and mutual understanding (Jonassen et al., 1999).

Contextual learning stresses the importance of situating the learning in a real-world setting. Learning with real-world settings supports learners' understanding and also the learners' ability to use new acquired knowledge in different situations and different settings (Jonassen et al., 1999).

These characteristics are intertwined, containing elements from each other which cannot be clearly separated. While designing learning situations and learning environments, there should be elements from all of these qualities in order to support students' meaningful learning (Jonassen et al., 1999).

\section{Qualitative Analysis of Online Courses in First Design Cycle}

During the autumn of 2004 and spring 2005 ISOverkosto project offered online courses for the participating institutions. High school teachers designed, tested and carried out 
these courses with students and local tutors. As these courses serve as templates for other teachers to adapt and modify, it is necessary to evaluate and offer suggestion for revision. Our role in this process has been twofold. Firstly we have organised in-service training for teachers at different levels and secondly in some areas of this ongoing work we have followed the process by the design research approach (Bereiter, 2002). In this approach, there is an attempt to design the educational intervention from both theoretical and practical knowledge on the basis of which further development cycle will be initiated. This analysis is the first iteration concerning teachers' technological pedagogical content knowledge and this also studies the suitability of the theoretical approaches taken, and their applicability to the practical issues of course evaluation.

Thirteen courses have been analysed using theory-based qualitative content analysis, starting with pre-defined categories based on Jonassen's criteria for meaningful learning. These categories served as a starting point for analysis, to categorize materials from the web-based learning environments, e.g., instructions, materials and learning assignments representing these qualities. In the next phase, the classified materials were subcategorized to present more precise pedagogical activities (Table 1). These activities are generalized containing variations between the courses. These subcategories and the information on interaction during the courses (Table 2), were used in the last phase of the analysis to categorize courses in different design patterns using the Hannafin's and Land's (1997) ideas of instructional design (Table 3).

The main difficulty was that some of the subcategories (pedagogical activities) could have been placed in two or more main categories. For example the expert task is placed under "constructive-category" because the process begins with individual construction of knowledge to gain expertise in the topic. It could however have been placed under the main category of "co-operative", because the teaching method necessitates collaborative activity in which the expert student teaches the topic to other students.

The courses were implemented in the web-based learning environment, Moodle. The number of students participating in these courses varied from 4 to 24 . In addition to the distance teacher who was responsible for the content and assessment, there was a local beginner online teacher who tutored the students. This analysis does not cover all possible interaction during the courses, only what is apparent from the online environment. The local tutors guided learners and occasionally also arranged face-to-face meetings. Tutors were kind of mediators between the learner and distance teachers. Each learner had one tutor locally, though one tutor was usually responsible for more than one learner.

\section{Results}

Table 1 summarises the different categories of pedagogical activities in the thirteen online courses. In the table the courses are classified, starting from the left according to the increasing level of criteria fulfillment for meaningful learning. 
Table 1

Pedagogical activities (Courses' pedagogical activities, main-categories and frequencies of activities in the courses analysed by researchers)

\begin{tabular}{|c|c|c|c|c|c|c|c|c|c|c|c|c|c|c|}
\hline \multirow[b]{2}{*}{ Main Category } & \multirow[b]{2}{*}{$\begin{array}{c}\text { Pedagogical } \\
\text { Activities } \\
\text { (sub categories) }\end{array}$} & \multicolumn{13}{|c|}{ Courses and frequencies of activities } \\
\hline & & 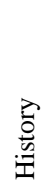 & 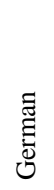 & 声 & 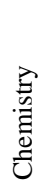 & 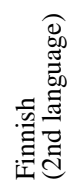 & 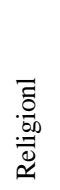 & $\begin{array}{l}\frac{5}{3} \\
\frac{.00}{60} \\
\text { जิ }\end{array}$ & $\begin{array}{l}\frac{0}{0} \\
\frac{.00}{2} \\
\simeq\end{array}$ & 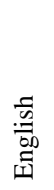 & 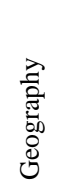 & $\frac{\overrightarrow{0}}{\stackrel{0}{0}}$ & $\begin{array}{l}\widehat{c} \\
\frac{0}{0} \\
\frac{0}{0} \\
\frac{0}{0} \\
0\end{array}$ & 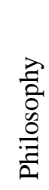 \\
\hline \multirow[t]{4}{*}{ Active } & Drill and practice & & 31 & 1 & 1 & & 3 & & 4 & 1 & 4 & 4 & 2 & \\
\hline & Essay writing & 2 & 2 & & & & 1 & 3 & & & 4 & 3 & 2 & 3 \\
\hline & $\begin{array}{l}\text { Self evaluated } \\
\text { assignments }\end{array}$ & 20 & 6 & 2 & 15 & 4 & & 9 & & 6 & & 8 & 1 & 6 \\
\hline & $\begin{array}{l}\text { Teacher evaluated } \\
\text { assignments }\end{array}$ & & 3 & 6 & 8 & 5 & 8 & 4 & 8 & 9 & 37 & 3 & & \\
\hline \multirow[t]{4}{*}{ Constructive } & Advanced organisers & & & & 2 & & & & 1 & & 4 & & 1 & 1 \\
\hline & $\begin{array}{l}\text { Experts tasks } \\
\text { (reciprocal) }\end{array}$ & & & & & & & & & & & 5 & & \\
\hline & Learning diaries & & 1 & & & & 1 & 1 & & 1 & & 1 & & \\
\hline & $\begin{array}{l}\text { Comparing external } \\
\text { standards }\end{array}$ & & & & & & 1 & & & 1 & & & & \\
\hline \multirow[t]{4}{*}{ Cooperative } & $\begin{array}{l}\text { Collaborative learning } \\
\text { assignments }\end{array}$ & & & & & & & & & & & & & 3 \\
\hline & $\begin{array}{l}\text { Discussion } \\
\text { assignments - teacher } \\
\text { lead }\end{array}$ & 2 & & & & 1 & 1 & 3 & 1 & 1 & 5 & 2 & 5 & \\
\hline & $\begin{array}{l}\text { Self-introduction - } \\
\text { discussion forums }\end{array}$ & 1 & & & 1 & 1 & & & & & & & 1 & \\
\hline & $\begin{array}{l}\text { Discussion forums as } \\
\text { bulleting board }\end{array}$ & & 1 & & & & & 1 & & 1 & & & & \\
\hline \multirow[t]{3}{*}{ Intentional } & $\begin{array}{l}\text { Creating personal } \\
\text { timetables }\end{array}$ & & & 1 & & & & & 1 & & & & & \\
\hline & $\begin{array}{l}\text { Choosing learning } \\
\text { assignments }\end{array}$ & & & 1 & & & & 1 & & 1 & 1 & & & \\
\hline & $\begin{array}{l}\text { Influencing evaluation } \\
\text { of the course }\end{array}$ & & & 1 & & & & & & 1 & & & & \\
\hline \multirow[t]{3}{*}{ Contextual } & Links for expert sites & & & & & & & & & & 1 & 1 & & \\
\hline & $\begin{array}{l}\text { Assignments from } \\
\text { real world issue }\end{array}$ & & & & & & & & & & 1 & & & \\
\hline & $\begin{array}{l}\text { Real world topic as a } \\
\text { theme for discussion }\end{array}$ & & & & & & & & & 1 & 1 & 1 & & 1 \\
\hline
\end{tabular}




\section{Support for Active Learning}

In Jonassen's criteria, active learning means more of a process in which the learner takes responsibility in setting the learning goals and results. In the courses analysed, the learner's role was mainly based on different learning assignments set up by the teacher. The subcategory drill and practice consisted of assignments that were usually series of multiple choice questions, that were designed so that the student got feedback immediately after giving the answer. The second type of assignments were self-evaluated tasks in which the student answers questions and then checks the right answers. These assignments were usually implemented with tools provided by Moodle, or quite often the assignments were also taken from textbooks. Typically the types of assignments above were used as tools for self evaluation and for extra practice.

The teacher evaluated assignments were similar to self evaluated assignments, the main difference being that the teacher gave personal feedback to students on their assignments. Typically, these kinds of assignments were short writings on the topic defined by the teacher. The subcategory "essay writing" was similar to teacher evaluated assignments, but usually the task in the essays was longer and the student could choose the topic him/herself. Essay writing gave students more responsibility in using different kinds of learning materials as a basis for their writing. Generally, all these assignments were designed so that the students worked alone and the results were evaluated by the teacher or by themselves, according to the teacher-made criteria. This main category (active) covers $77 \%$ of the types of activities in these courses.

\section{Support for Constructive and Reflective Learning}

Teachers used several methods to support knowledge construction that takes into account the learners' prior knowledge. Teachers used some kind of advanced organizers as learning assignments, and with these assignments, teachers encouraged learners to think and evaluate their prior knowledge on the topic. For this purpose, teachers also introduced external standards by which students evaluated and compared their own skills.

To support knowledge construction, one of the teachers used expert tasks in which the learners

took one particular topic, made a short report on it to present to others, and later, acting as an expert, answered questions put by the other students. This type of activity provided possibilities for other students to consider different ideas, opinions and conceptions on the topics and to resolve conflicts amongst their own, peer students' and (course) content knowledge. Learning diaries were used in five courses to support the learners' active reflection. Students were asked to report on the diary, what they had done, and evaluate their continual learning process. Only $7 \%$ of the course features belonged to this main category. 
Table 2

Discussions (Forums in course, refers to the amounts of discussion forums used in the Moodle environment. Topics, in parenthesis, mean the number of discussion threads in one discussion forum. Notes posted per topic, refers to the number of notes in one discussion thread.)

\begin{tabular}{lccc}
\hline Course & $\begin{array}{c}\text { Forums } \\
\text { in course }\end{array}$ & \multicolumn{1}{c}{$\begin{array}{c}\text { (Topics) Notes posted } \\
\text { per topic }\end{array}$} & $\begin{array}{c}\text { Notes } \\
\text { on course }\end{array}$ \\
\hline Finnish & 0 & $(0) 0$ & 0 \\
German & 1 & $(0) 0$ & 0 \\
History & & 1 \\
Chemistry & 2 & $(1) 1$ & 2 \\
Religion 1 & 2 & $(2) 2$ & 3 \\
Religion 2 & 1 & $(1) 3$ & 4 \\
Geography & 1 & $(2) 1,3$ & 11 \\
Biology & 5 & (5) $2,1,4,1,3$ & 15 \\
Finnish as second language & 7 & $(5) 5,2,2,2,4$ & 21 \\
English 2 & 2 & $(6) 1,3,1,7,5,4$ & 34 \\
English 1 & 1 & $(7) 3,4,4,6,9,7,1$ & 84 \\
Psychology & 2 & $(10) 11,4,1,14,9,3,4,8,1,1$ & \\
& 6 & $(34) 4,4,4,4,2,2,2,2,2,2,4,2,4,4$, & \\
Philosophy & & $2,2,2,2,5,1,3,4,1,2,1,2,6,4$, & \\
& 3 & $(28) 7,4,6,1,11,3,9,6,5,2,2,5,4,1$, & 138 \\
\hline
\end{tabular}

\section{Support for Co-operative Learning}

Since discussion forums are quite often used to support group activities and collaboration, their use is categorised here. In most of these courses learners studied the materials and accomplished the learning tasks mainly by themselves. As we can see in Table 2, the role of the discussions was minimal in the first five courses. It was typical that these courses were based more on the students' independent work. Each discussion forum usually consisted of several discussion topics, but there were courses in which there were no discussion notes in the forums (see German).

In the rest of the courses, collaboration and discussion played a more central role. However, the main use of this tool was in the courses analysed to use these forums as learning assignments in which teachers asked questions and learners answered them. These assignments were quite similar to teacher evaluated assignments but the main difference was that these answers were visible to other students and that each learner was able to read eachothers' texts and to comment on them. The interaction between students was minimal and the discussion threads were quite short (see geography, and Finnish as the second language in Table 2). In three courses, teachers used discussion forums as bulleting boards, where they presented questions frequently asked etc. (moodle-news not included in Table 2). In addition to these discussions, teachers also used discussion forums to support construction of the online community. In these, the conversation themes 
were loosely connected to the topic and the main idea was to become acquainted with other students (see English 1).

The fourth way of using discussion forums focused more on the construction of knowledge based on collaborative activities. In one course the teacher used collaborative learning assignments, using students' initiated discussions as a method to support learning. In this course the learners and the teacher discussed the topics in discussion forums, so that learners brought their own ideas on the topic to the discussion forum. The discussion threads were longer than in other courses (see philosophy in Table 2). Learners had the opportunity to become familiar with different ideas and were able to change their conceptions and knowledge structures according to these new situations. $11 \%$ of the course features were included in this main category.

\section{Support for Intentional Learning}

Teachers had utilized some methods to support students' intentionality. In two courses, teachers asked learners to make their own timetables in order to support better independent studying. In four courses learners also had the possibilities of choosing some of the learning assignments which were of interest to them. This was mainly used in assignments for short writing. Quite often teachers also provided extra material which learners could use according to their own learning needs.

In some courses students were able to express their opinion about the evaluation of the course, for example, the use of a final examination, portfolio, or some other evaluation method. Students could also influence the evaluation themselves by taking some extra assignments and participating in discussion. Only three percent of the course features were put into this main category.

\section{Support for Contextual Learning}

The learning context was constructed by making links to web-sites which represent expert knowledge, or to magazines connected to the topic. This way the student could follow activities in real world environments. Some learning assignments dealt with real world issues like tropical hurricanes etc. In these cases, students had to write about the issue or make graphs according to information on sites. The tasks also assumed that students were able to apply the content knowledge of the course.

In the language courses, teachers used real world topics as themes for discussions. Students were asked to make presentations and discuss some topic on the basis of the web sites, for instance information gathered from tourist agencies. Two percent of the course features were included into this main category. 


\section{Overall Structure of the Courses}

In the thirteen courses analysed teachers, had designed the courses very carefully before the course began, so that the students' role was mainly to follow the pre-defined instructions and guidance provided by the teacher on the learning material. The structure of all thirteen courses was very clear cut and probably easy to follow. The pedagogical idea behind the courses was very similar to design models of Gagne and Merril (1990). The target knowledge or skill designed in the course was divided into topics. Each topic consisted of guiding materials for learning, references to textbooks, materials presenting essential themes and facts and also learning tasks. In some cases there were discussion forums and learning portfolios too. The role of the learner was to proceed through the topics in the order defined by the teacher, studying the learning material and accomplishing the learning tasks.

\section{Four Different Design Patterns for Online Courses}

According to Hannafin and Land (1997) the instructional design process (of the learning environment) is based on psychological, pedagogical, cultural, technical and practical elements. The psychological element consists of the knowledge about how people learn, how the mind works, how to support learning. From this perspective Hannafin and Land (1997) divide the design approach in to two main perspectives: teacher-centred and learner-centred. The differences are based on the roles of teacher and learner. In our results we can see that although learning in the web-based learning environment places the student in the central role, the courses analysed were mainly designed and based on teacher-centred principles.

Based on our analysis we noticed that as courses can be divided into teacher and learner centred courses, they can also be divided by their collaborative qualities. On some courses students studied alone, with learner support when needed. On other courses learners worked collaboratively, discussing the learning topics. Based on these elements we divided the courses analysed into four categories (Table 3).

Table 3

Course design patterns

\begin{tabular}{lll}
\hline & Individual & Collaborative \\
\hline Teacher-centred & $\begin{array}{l}\text { Pattern 1. Working alone, teacher } \\
\text { directed studying, preparing for the test. } \\
\text { Teacher offers constant feedback }\end{array}$ & $\begin{array}{l}\text { Pattern 2. Based on pre-defined group } \\
\text { discussions initiated and guided by the } \\
\text { teacher }\end{array}$ \\
Learner-centred & $\begin{array}{l}\text { Pattern 3. Working alone, self-directed } \\
\text { studying guided by the material. } \\
\text { Teacher available on demand }\end{array}$ & $\begin{array}{l}\text { Pattern 4. Student group invents } \\
\text { (sub)problems and tasks, e.g., solving a } \\
\text { problem or making an inquiry based on } \\
\text { the context and material }\end{array}$ \\
\hline
\end{tabular}


Pattern 1 . The teacher-centred individual pattern is based on a very well guided learning process, in which the teacher and also the learning material are in a central position. The structure of the course brings to mind normal contact teaching where the teacher controls the learning process using tasks, assignments, evaluation and learning material. The interaction between students and teachers is most significant, typically using teacher evaluated assignments. Students send the learning assignments to the teachers who then give feedback. The interaction among the students themselves is quite minimal, even though it was typical for teachers to use discussion assignments. The discussion messages were usually very short excerpts, containing only a few issues. These courses were also very clearly pre-planned and the structure easy to follow, containing a lot of guiding material.

Pattern 2. Teacher-centred collaborative pattern. The teacher and students were more actively involved in the learning process using asynchronous discussion forums. The teachers' role is important in guiding students to think and in helping them to reflect their ideas and learning experiences. The aim is for students to become familiar with the topic through different material such as textbooks and web pages. Then, guided by the teacher, students apply this knowledge in discussion, typically in collaborative learning assignments and expert tasks (Table 1). The aim is to bring forth the students' own conceptions about the topic, to help them to reflect and evaluate both their own and other students' conceptions, and to support constructive learning. Mostly ready-made learning material was used to build the context for online discussions.

Pattern 3. Learner-centred individual pattern. This pattern consists basically of selfstudy learning material. The student uses ready-made material whihc includes guides concerning what and how the student should learn, also what material is to be studied. The course material was designed to offer strong scaffolds, guiding learners to focus on essential points of the topic. The teacher was supposed to be available only when needed. Generally these courses contained a lot of tools for self evaluation, for example drill and practice, and self evaluated assignments. The student's role is to study independently with the help of extra guidance material in preparation for the test.

Pattern 4. Learner-centred collaborative pattern. The potential of the fourth pattern was not completely fulfilled, only the philosophy-course and biology-course had common features. Pattern four corresponds to ideas of CSCL stressing student centred, collaboration oriented teaching and learning, where the teacher's role is mainly supporting

Table 4

Courses and their design pattern

\begin{tabular}{lll}
\hline Pattern 1 & Pattern 2 & Pattern 3 \\
\hline Finnish as 2nd language & Biology & Chemistry \\
Religion 1 & Psychology & Finnish \\
English 1 & Philosophy & German \\
Religion 2 & & History \\
English 2 & & \\
Geography & & \\
\hline
\end{tabular}


the learning process, and the student groups themselves are responsible for the learning process. In some of the courses, we found elements that meet this criteria, e.g., argumentative discussion in the philosophy-course, expert tasks in the biology-course, and community building with self introduction. However, neither teachers nor the students totally relied on the student-centred collaborative approach; the expert task didn't lead to active collaborative knowledge building in further discussions and the philosophy course discussions were initiated by the teacher. For these reasons these courses were interpreted as corresponding to Pattern 2.

Overall, although students had some possibilities to contribute to the course and learning process, the teachers had planned quite strictly as to how the course would proceed, so the learners' only has a minimal amount of influence. The following course instructions given to students seem to enlighten the issue (Finnish language course): "You are supposed to study individually, but not alone. It is important, that you contact me immediately when something puzzles you. We will seek solutions to the problems together."

\section{Discussion}

The analysis was started with categories based on Jonassens' theory of meaningful learning. The five main categories provided a workable framework to start the analysis. It has also served as a pre-organizer for face-to-face meetings with teachers at in-service training sessions, after the courses had been conducted. Although the categorization of different pedagogical activities implemented with various tools provided a challenging task for us, it showed some general methods which teachers utilize when they design their online courses. The classification of the pedagogical activities into different categories can be argued to represent teachers' conceptions about pedagogical aims and methods. It also reveals some key characteristics of these teachers' technological pedagogical content knowledge and helps planning of in-service teacher training. Our result is in accordance with earlier research on teacher conceptions of learning and teaching (Marton et al., 1993; Kember, 1997) although teacher centred teaching and learning methods were overemphasized.

The analysed courses mostly utilised teacher-centred, individual teaching methods. The structures of the courses were very strictly defined and probably easy to follow. Learners were supposed to proceed through pre-defined, teacher-designed learning traits by utilizing teacher's support, guiding materials, learning material and text books. Compared to the principles of CSCL and results of Harasim's (2000) research concerning use of online education in Virtual-U, these courses emphasized self-paced studying with minimal peer interaction. According to Peruski and Mishra (2004), teaching and learning in an online context provided teachers with opportunities to rethink and evaluate their course design and teaching methods. It seemed that teachers had only used the more traditional teacher-centered methods when designing courses for the online environment. The lack of collaboration and peer-interaction online was probably substituted mainly by working with local tutor teachers who had counselled learners and also arranged faceto face meetings, in which learners could share their experiences and get feedback for 
their work. Even when these courses are considered to follow what Harasim calls "mixed mode courses", students' peer interaction in these courses was very low, compared to Harasim's results, with only a few reply messages. Students did not participate in online discussions unless the participation was either compulsory or gave extra credits for the final evaluation. Discussions, especially argumentative discussions, require skills that have to be practised (Marttunen et al., 2005). According to Kuusinen (2001), the learning models that learners get from Finnish schools, emphasizes individual work which does not encourage collaborative learning and working.

The results of this study will be used as a basis for distance teachers' further development and the planning of in-service training. In the light of this study, there is a need to find ways to help teachers to implement strategies of meaningful learning, and encourage teachers to find out ways to use more collaborative learning approaches in their online course designs. Our post-course results are similar to results at the beginning of the course design process of Koehler's and Mishra's (2005) research in which they claim that during a semester-long course the participants had got integrated knowledge of technology and pedagogy. Changing the teaching and learning methods from teacher-centred to learner-centred, has turned out to be a challenging task (Glasson and Lalik, 1993). The framework of teacher's technological pedagogical content knowledge seems to offer valuable concepts to evaluate and support teachers' efforts to conduct online teaching at the high school level.

\section{References}

Bereiter, C. (2002). Design research for sustained innovation. Cognitive studies. Bulletin of the Japanese Cognitive Science Society, 9(3), 321-327.

Boulton-Lewis, G., D. Smith, A. McCrindle, P. Burnett and K. Campbell (2001). Secondary teachers' conceptions of teaching and learning. Learning and Instruction, 11(1), 35-51.

Clark, C., and P. Peterson (1986). Teachers' thought processes. In M. Witrock (Ed.), Handbook of Research on Teaching, 3rd ed. Macmillan, NY. pp. 255-296.

Collins, A., J. Brown and S.E. Newman (1989). Cognitive apprenticeship: teaching the crafts of reading, writing, and mathematics. In L.B. Resnick (Ed.), Knowing, Learning, and Instruction: Essays in Honour of Robert Glaser. Erlbaum, Hillsdale, NJ.

Cornett, J., C. Yeotis and L. Terwilliger (1990). Teacher personal practical theories and their influence upon teacher curricular and instructional actions: a case study of a secondary science teacher. Science Education, 74(5), 517-529.

Gagne, R., and M. Merill (1990). Integrative goals for instructional design. Educational Technology Research and Development, 38(1), 23-30.

Glasson, G., and R. Lalik (1993). Reinterpreting the learning cycle from a social constructivist perspective: a qualitative study of teachers' beliefs and practices. Journal of Research in Science Teaching, 30(2), 187-207.

Hannafin, M., and S. Land (1997). The foundations and assumptions of technology-enhanced, student-centered learning environments. Instructional Science, 25, 167-202.

Harasim, L. (2000). Shift happens: online education as a new paradigm in learning. The Internet and Higher Education, 3(1-2), 41-61.

Jennings, M., and D. Dirksen (1997). Facilitating change: a process for adoption of web-based instruction. In B.H. Khan (Ed.), Web-based Instruction, 1 ed. Educational Technology Publications, Englewood Cliffs, NJ. pp. 111-116.

Jonassen, D. (1995). Supporting communities of learners with technology: a vision for integrating technology with learning in schools. Educational Technology, 35(4), 60-63. 
Jonassen, D., K. Peck and B. Wilson (1999). Learning With Technology: A Constructivist Perspective. Upper Saddle River, NJ Prentice Hall.

Joyce, B., and M. Weil (1986). Models of Teaching. Third Edition. Prentice-Hall, London.

Kember, D. (1997). A reconceptualisation of the research into university academics' conceptions of teaching. Learning and Instruction, 7(3), 255-276.

Koehler, M.J., and P. Mishra (2005). What happens when teachers design educational technology? The development of technological pedagogical content knowledge. Journal of Educational Computing Research, 32(2), 131-152.

Koschmann, T. (1996). Paradigm shifts and instructional technology: an introduction. In T. Koschmann (Ed.), CSCL: Theory and Practice of an Emerging Paradigm. Lawrence Erlbaum, Mahwah, New Jersey. pp. 1-23.

Kuusinen, R. (2001). Ongelmana yhteistyökyvyttömyys? Teoreettisen ymmärryksen etsintää web-avusteiselle tiedontuottamisyhteistyölle (in Finnish, Problems with collaborative skills? Searching theoretical understanding for collaborative web assisted knowledge construction). University of Helsinki.

Lipponen, L. (2002). Exploring foundations for computer-supported collaborative learning. In G. Stahl (Ed.), Computer Support for Collaborative Learning: Foundations for a CSCL community. Proceedings of the Computer-supported Collaborative Learning 2002 Conference. Erlbaum, Hillsdale, NJ. pp. 72-81.

Marland, P. (1998). Teachers' practical theories: implications for preservice teacher education. Asia-Pacific Journal of Teacher Education, 1(2), 15-23.

Marland, P., and B. Osborne, B. (1990). Classroom theory, thinking and action. Teaching and Teacher Education, 6(1), 93-109.

Marton, F., G. Dall'Alba and E. Beaty (1993). Conceptions of learning. International Journal of Educational Research, 19(3), 277-300.

Marttunen, M., L. Laurinen, L. Litosseliti and K. Lund (2005). Argumentation skills as prerequisites for collaborative learning among Finnish, French and English secondary school students. Educational Research and Evaluation, 11(4), 365-384.

Mellado, V. (1998). The classroom practice of preservice teachers and their conceptions of teaching and learning science. Science Education, 82(2), 197-214.

Mishra, P., and M.J. Koehler (in press). Technological pedagogical content knowledge: A framework for integrating technology in teacher knowledge. Teachers College Record.

Paavola, S., L. Lipponen and K. Hakkarainen (2002). Epistemological foundations for CSCL: a comparison of three models of innovative knowledge communities. In G. Stahl (Ed.), Computer Support for Collaborative Learning: Foundations for a CSCL community. Proceedings of the Computer-supported Collaborative Learning 2002 Conference. Erlbaum, Hillsdale, NJ. pp. 24-32.

Peruski, L., and P. Mishra (2004). Webs of activity in online course design and teaching. ALT-J, Research in Learning Technology, 12(1), 37-49.

Schank, R., and C. Cleary (1995). Engines for Education. Erlbaum Assoc, Hillsdale, NJ.

Shulman, L. (1986). Those who understand: knowledge growth in teaching. Educational Researcher, 15(2), $4-14$.

Shulman, L. (1987). Knowledge and teaching: foundations of the new reform. Harward Educational Review, 57(1), $1-21$.

Virnes, A., and L. Suonio (2004). Finland educational network combining present and new forces as parts of a robust, apt and educationally equal Eastern Finland. In Proceedings of the EDEN 2004 Annual Conference. Budapest University of Technology and Economics Budapest, Hungary. pp. 207-213. 
T. Valtonen is PhD student, master of education. Teemu Valtonen has been working at the University of Joensuu in Department of Applied Education. Since 2001 instructor in teachers' in-service training, research amanuensis in Verkkosalkku2 - project. Currently working with ISOverkosto - project.

J. Kukkonen is master of science (MSc). Jari Kukkonen, instructional designer, at the University of Joensuu. Has worked as full-time instructor, ICT in education, senior assistant, ICT in education. Organiser of open and distance education in teacher education, pedagogical qualification. Chairman of the expert unit in information and communication technology in education (TOTY).

A. Wulff works as a project coordinator in an ESF funded Eastern Finland Educational Network project. She received her master's and PhD (1996) degrees in environmental science from the University of Kuopio, Finland. She has worked as an visiting scientist at the Institute of Terrestrial Ecology, Edinburgh UK for one year. Her list of publications (http://koti.mbnet.fi/wulff/anuwulff_publications010406.htm) contains 18 original scientific papers (in english), 8 conference papers and 33 conference abstracts. She has supervised 12 master's degrees and one $\mathrm{PhD}$ degree and has versatile administration experience. Anu Wulff has received twice "The teacher of the year" award at the University of Kuopio. After serving as a research assistant and assistant professor in applied botany at the Department of Environmental Science for 12 years, she moved on to develop online learning, first as a virtual university coordinator (2000-2003) at the Learning Centre of University of Kuopio and since 2004 at the city of Kuopio. Her special interests and expertise lies on online guidance and assessment. At her present work Anu Wulff is responsible for pedagogical advisory system (Moodle) and training secondary education teachers for online teaching. Anu can be contacted at anu.wulffatkuopio.fi. 


\title{
Viduriniu mokyklu mokytoju pamoku planavimas ir ju profesionalumas internetinio mokymo srityje
}

\author{
Teemu VALTONEN, Jari KUKKONEN, Anu WULFF
}

Straipsnyje aptariamos virtualiu viduriniu mokyklu tinklo plètra, kuriant internetini mokyma bei kasdieninę tokių mokyklų veiklą. Tyrimas atliekamas remiantis Europos socialinio fondo finansuojamu projektu „Rytų Suomijos Švietimo tinklas“, apimančių 36 vidurines mokyklas. Atliekant ši projektą organizuojami kursai, kuriems pasitelkiamos žiniatinklinės mokymosi aplinkos. Publikuojamo tyrimo tikslas - ištirti mokytojų technologines-pedagogines žinias bei išsiaiškinti, kokias pedagogines priemones mokytojai pasitelkia rengdami internetinio mokymo programas ir jas mokydami. Straipsnyje analizuojama trylika interneto kursu ir remiantis šia analize išskiriami keturi atskiri kursų rengimo modeliai. Labiausiai paplitęs interneto kursų rengimo modelis yra orientuotas i mokytoja, susitelkiant prie individualaus mokymosi proceso, kuriam deramai vadovaujama. Atskleidžiamas mokytoju technologiniu-pedagoginiu žiniu ugdymo poreikis siekiant, kad būtų kuriami labiau interaktyvūs tokiu pamokụ modeliai. 